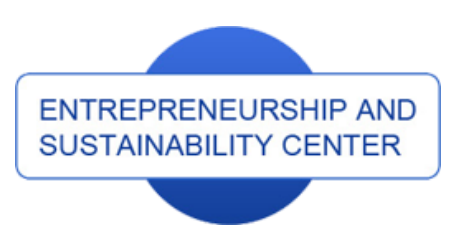

Publisher

http://jssidoi.org/esc/home
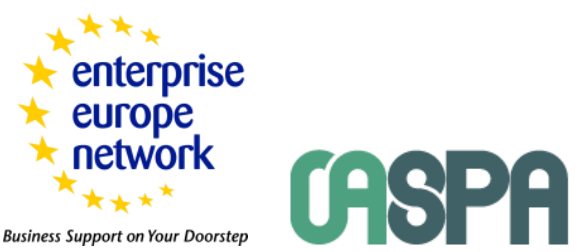

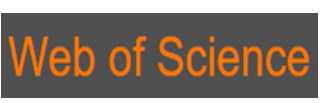

Clarivate
Analytics

\title{
RELATIONSHIP OF GENDER TO THE POSITION OF SLOVAK UNIVERSITY STUDENTS ON THE SOCIO-ECONOMIC DETERMINANTS OF THE BUSINESS ENVIRONMENT AND THE DEVELOPMENT OF ENTREPRENEURSHIP
}

\author{
Jaroslav Belas', Beata Gavurova², Martin Cepel $^{3}$, Anna Kotaskova ${ }^{4}$ \\ ${ }^{1}$ Tomas Bata University in Zlín, Faculty of Management and Economics, \\ Mostni 5139, 76000 Zlín, Czech Republic \\ ${ }^{2}$ Technical University of Kosice, Faculty of Economics, \\ Němcovej 32, 04001 Kosice, Slovak Republic \\ ${ }^{3}$ Paneuropean University in Bratislava, Faculty of Economics and Business \\ Tematinská 10, 85105 Bratislava, Slovak Republic \\ ${ }^{4}$ Paneuropean University in Bratislava, Faculty of Economics and Business \\ Tematinská 10, 85105 Bratislava, Slovak Republic
}

E-mails:1belas@,utb.cz,2 beata.gavurova@,tuke.sk, ${ }^{3}$ cepel@,benzinol.com, ${ }^{4}$ anna.kotaskova@,gmail.com

Received 15 June 2018; accepted 20 October 2018; published 30 December 2018

\begin{abstract}
The current competitive environment and globalization processes create pressures on education processes at universities. Increasing business opportunities, business creation and business development is also one of the forms of unemployment. To do this, education for entrepreneurship at various levels of education is essential, as well as active support for infrastructure resources in the economy. High school students represent a significant group of young people with a sufficient knowledge base, analytical, creative and practical skills that are essential to building entrepreneurial self-confidence. Many research studies declare gender differences in the approach to entrepreneurship that have an impact on decision-making processes in the application of graduates of higher education. To eliminate these differences, it is important to explore in more detail the factors that cause them. This was also an incentive for our research. We realized online survey among students of Slovak universities in 2017. Our objective was to find which socioeconomic determinants of entrepreneurship are dependent on gender of students at Slovak universities. We wanted to know also how propensity for entrepreneurship is influenced by gender. From our results we can conclude that gender of students is significant determinant of attitude toward both entrepreneurship environment $(\mathrm{p}<0,05)$ and especially entrepreneurship propensity $(\mathrm{p}<0,001)$. Men are more self-confident from the viewpoint of actual and possible entrepreneurship than women. The results of our research can be beneficial to relevant policy makers as well as to experts involved in the development of regional development plans, business support and education experts, etc.
\end{abstract}

Keywords: Gender dependence; socioeconomic determinants; entrepreneurship environment; entrepreneurship; entrepreneurial competences; educational programs; entrepreneurial opportunities; barriers to business development.

Reference to this paper should be made as follows: Belas, J.; Gavurova, B.; Cepel, M.; Kotaskova, A. 2018. Relationship of gender to the position of Slovak University students on the socio-economic determinants of the business environment and the development of entrepreneurship, Entrepreneurship and Sustainability Issues 6(2): 968-978. http://doi.org/10.9770/jesi.2018.6.2(33)

JEL Classifications: I21, I23, L26. 
Additional disciplines sociology; psychology; educology; information and communication.

\section{Introduction}

In the current period, the interest in the development of entrepreneurship among young people is increasing. It is related to the pressures on the economic growth of the country, the increasing competitiveness of companies as well as technological and innovative developments (Stankevičiené et al. 2017; Dul'ová Spišáková et al. 2017). Business development in the country is also linked to the structural aspects of the economy, with a segment of small and medium-sized businesses taking the lead (Androniceanu, 2015; Ključnikov et al. 2016; Machová et al. 2017; Dobeš et al. 2017; Kozubíková et al. 2017). Their emergence and action is important especially where conditions for the operation of large institutions are not suitable. This concerns less developed areas, areas with high unemployment, and so on (Misoska et al., 2016). It is these aspects that are very important in supporting the entrepreneurial activities of young people (Staniewski \& Awruk, 2015). An important role is played by business education, which is strongly criticized (Belas et al. 2017). One reason is the poor reflection of these educational programs on changes in the economic and business environment of the country, insufficient links with firms, and insufficient penetration of innovation in education processes (Bedzsula et al. 2016). New education programs must focus on entrepreneurial competences, multi-dimensional problems, creativity, creative and innovative activities, and so on (Dragolea et al. 2017; Estaswara, 2016). This also requires a specific approach to learningbased learning processes, as students perceive particular aspects and conditions of business, and whether their tendency towards entrepreneurship is modifiable by promoting quality learning processes (Upadhyay, 2017). These aspects supported us in a deeper study of the issue where we focused on the gender differences in attitudes of university students in Slovakia towards the socio-economic determinants of the business environment and the development of entrepreneurship. Main objective of our paper is to find which socioeconomic determinants of entrepreneurship are dependent on gender of students at Slovak universities. We wanted to know also how propensity for entrepreneurship is influenced by gender.

\section{Literature Review}

Available research studies provide interesting insights into the quality of entrepreneurial education and its determinants. Askun and Yildirım (2011) examined the quality of entrepreneurial education at public higher education institutions in Turkey. Authors surveyed the websites of 360 Academic Units. Business authors understand this as a means of eliminating unemployment and other negative issues related to the global economic crisis. Improved human resources and a knowledge base are essential to improve business and support entrepreneurship. The authors call for the need to improve entrepreneurial courses in higher education. Enterprise education is one of the major infrastructure resources of the business economy, as it helps individuals to acquire business skills and knowledge. Many researches show that starting a business is related not only to education but also to knowledge and individual abilities. Entrepreneurial education takes the form of formal education, so universities should use the learning process as a real opportunity for students to set up businesses and use business cooperation. The conclusion of the study is of an institutional nature. The authors point out that while there are government, industrial and non-governmental organizations' efforts to develop the business environment in Turkey (in the legislative, knowledge and human infrastructure area), business development is insufficient in comparison to other advanced Eastern European countries. There are no coordinated national education strategies and policies implemented in industry strategies, which weakens the development of entrepreneurship. Research findings unequivocally confirm that courses in entrepreneurship at public higher education institutions in Turkey are insufficient to provide the necessary knowledge and skills for creating new business entities. Similar findings have also been found by experts Riel et al. (2015). In their research study, they focus on pan-European certified education and training programs. The authors point out that preparing young people for entrepreneurship is a 


\section{The International Journal}

ENTREPRENEURSHIP AND SUSTAINABILITY ISSUES

ISSN 2345-0282 (online) http://jssidoi.org/jesi/

2018 Volume 8 Number 2 (December)

http://doi.org/10.9770/jesi.2018.8.2(33)

strategic goal in a knowledge-based economy to ensure sustained growth and essential for the successful start-up of small and medium-sized businesses that can sustain themselves in the business environment under the pressure of innovation. The authors emphasize the importance of education in the context of creating an innovation potential that is essential for business. They analyze the bjectives in training programs: developing entrepreneurial endeavours, educating students about the skills they need for entrepreneurship, developing their entrepreneurial ability to identify and exploit opportunities. Torres et al. (2017) examined gender differences in student decision making. Questionnaire research was carried out on a sample of 1493 students. Based on findings from other studies, women also decided to become entrepreneurs much less than men. Women are more attributed to their success by external circumstances than by their own abilities or efforts. Based on the findings of their findings, greater efforts to start a business were found among those students whose parents or relatives or friends are doing business. This business effort is much higher for students living in families where both parents run their own businesses. The authors also point to interesting findings that students who have expressed interest in doing business are also able to undertake higher risks (exhibiting greater tolerance for risk). Quality business education, business support by family members as well as the ability to undertake business risks are important attributes of business development in the country. Cavaller (2011) points out in his study the need to implement new systems to measure the performance and efficiency of university education. By giving the university the character of a business university, it requires a different approach to assessing the performance and efficiency of its learning processes. Cavaller highlights problems with the application of new methodologies in assessing heterogeneous education systems. According to the author, the new model of the university must identify and evaluate the actors of education, concentrate on analyzing the provided knowledge base for the students, with an emphasis on analytical, practical and creative skills. Pihie and Bagheri (2011) examined their differences in the entrepreneurial self-assessment of teachers and students of secondary vocational schools. A survey sample was made up of 315 teachers and 3000 students from technical and vocational secondary schools. They have used the Business SelfAssessment Tool (ESE) in both students and pedagogues. The authors point out that business education is currently scattered throughout the country. The results of their analyzes show that there is a significant difference in the results of business self-evaluation between teachers and students. Business confidence dominated most among the teachers, business self-sufficiency dominated among students. Differences in entrepreneurial efficacy between teachers and students point to the need for targeted and effective interventions in business education at technical and vocational schools to ensure the realization of the idea of "entrepreneurship as an alternative career". These research findings can be important for educators in creating specific education and training programs. The focus is on building effective education strategies and using effective methods by which teachers gain high motivation and confidence in their ability to effectively teach entrepreneurship, apply entrepreneurial teaching methods, increase their entrepreneurial efficiency, and etc. Belloti et al. (2012) focused on identifying the necessary knowledge and skills for prospective entrepreneurs. They took the form of interviewing and survey. The authors point out that entrepreneurial education in the EU lags behind the US and Canada. Business is currently underrepresented in education policies. Of the 21 million students in the EU, only about 5 million are involved in business. The problem is the fact that business education is offered only by business schools. Innovative and effective business ideas come from technical, scientific and creative studies. Authors at the conclusion of the study highlight shortcomings in the concepts of entrepreneurial education at universities, and insufficient solutions to these problems in national education policy as well as at the strategic level of the education system of the country. They also call for the need to increase skills for entrepreneurial pedagogy, which are different from those for other academic subjects. Improving entrepreneurship education should be a challenge for today's knowledge-based society.

\section{Data and methodolog}

All data were gathered by online survey that concerned attitude toward entrepreneurship among Slovak university students $(216$ men $(38,0 \%)$ and 352 women $(62,0 \%)$ in 2017. Together we gathered data of 40 indicators. They 
can be divided into ten groups. Indicators of first nine groups are rather input - entrepreneurship environment. They characterize attitude of students towards socioeconomic determinants of entrepreneurship in Slovakia. The tenth group was intended for entrepreneurship propensity (more output character). Each group contains four indicators. Complete list of all used indicators is as follows:

E1: Social environment

$\mathrm{X} 11$ : There is an entrepreneur in my family and I highly respect him/her.

$\mathrm{X} 12$ : Society in general appreciates entrepreneurs.

X13: Politicians as well as public consider entrepreneurs to be beneficial for society.

X14: Media provide true information regarding status and activities of entrepreneurs.

E2: Entrepreneurial support from state

$\mathrm{X} 21$ : The state supports entrepreneurship by using its tools.

$\mathrm{X} 22$ : The state creates high-quality conditions for starting an entrepreneurship.

X23: The state financially supports entrepreneurship.

$\mathrm{X} 24$ : Legal conditions for doing entrepreneurship are of high quality.

E3: Macroeconomic environment

X31: I consider the macroeconomic environment of my country to be positive for doing entrepreneurship.

X32: The state of macroeconomic environment of my country supports starting an entrepreneurship.

X33: Present macroeconomic environment does not prevent me from starting an entrepreneurship.

X34: Present level of basic macroeconomic factors (GDP, employment, inflation) supports entrepreneurship and creates interesting entrepreneurship opportunities.

E4: Quality of entrepreneurship environment

X41: entrepreneurship environment of my country is of good quality and convenient for starting an entrepreneurship.

X42: The entrepreneurship environment of my country is relatively risk-resistant and enables to start an entrepreneurship.

X43: Conditions for doing entrepreneurship have improved in my country in the last five years.

X44: The amount of administrative work of entrepreneurs in my country has decreased in the last five years.

E5: Access to the financial resources

X51: There is no intensive financial risk in the entrepreneurship environment, i.e. having limited access to external financial sources, bad payment habits, etc.

X52: Entrepreneurship entities have easy access to bank credits.

X53: I consider the credit conditions of commercial banks in my country to be appropriate.

X54: The interest rates of commercial banks support entrepreneurship activities.

E6: Quality of university education

X61: I consider university education of my country to be of good quality.

X62: I consider the educational structure at my faculty (university) to be of high quality.

X63: The knowledge acquired at my faculty (university) will help me when doing entrepreneurship.

X64: The knowledge acquired by students in my country will help them to start an entrepreneurship.

E7: Personality traits

X71: An entrepreneur does not have to have any special innate abilities.

X72: The most important characteristics of an entrepreneur are specialization, persistence, responsibility, and riskresistance.

$\mathrm{X73}$ : It is easier to do entrepreneurship if close relatives are in entrepreneurship. 
X74: Every person has certain prerequisites for doing entrepreneurship.

E8: Entrepreneurships advantages

X81: The advantages of entrepreneurship outnumber the disadvantages.

X82: An entrepreneur is wealthier and having a higher social status.

X83: Doing entrepreneurship enables to have career growth and interesting job opportunities.

X84: Doing entrepreneurship enables to make use of own abilities.

E9: Entrepreneurship disadvantages

X91: The disadvantages of entrepreneurship outnumber the advantages.

$\mathrm{X} 92$ : The disadvantage of doing entrepreneurship is not having a regular income.

X93: The negative aspect of doing entrepreneurship is the fact that an entrepreneur does not have time to be with his/her family.

X94: The disadvantage of doing entrepreneurship is not having good reputation within society.

Y: Entrepreneurial propensity

Y1: I am very interested in entrepreneurship.

Y2: I am convinced that I will start an entrepreneurship after I graduate from university.

Y3: In case nothing unexpected happens, I will start an entrepreneurship within three years latest.

Y4: At present, I have entrepreneurship activities.

Measure of student agreement with statements about entrepreneurship conditions and about entrepreneurial propensity was graded by typical ordinal five-level Likert scale: 1 -Strongly disagree, 2 - Disagree, 3 - Neither agree, nor disagree; 4 - Agree, 5 - Strongly agree.

For achievement of our objective we used suitable statistical methods: descriptive statistics, parametric and nonparametric (Wilcoxon test) analysis of variance (ANOVA) and discriminant analysis (for possible multivariate classification of gender based on socioeconomic determinants and on propensity for entrepreneurship. All statistical reports and graphs were made by statistical system IBM SPSS version 19. We wanted to know association of gender to location parameters (arithmetic mean and median) of available entrepreneurial indicators. That is why we tested possible shift in mean and median in all available indicators by gender of students at Slovak universities.

\section{Results}

Basic statistical characteristics (arithmetic mean, median and sample standard deviation) of students' attitudes towards entrepreneurship grouped by gender are in table 1 (significant differences in analysed indicators according to gender are in bold).

Table 1. Statistical characteristics of attitude of students from Slovak universities toward entrepreneurship grouped by gender

\begin{tabular}{|l|l|l|l|l|l|l|l|l|l|l|l|l|l|l|}
\hline Gender & \multicolumn{3}{l}{ Men $(\mathrm{n}=216)$} & \multicolumn{3}{l|}{ Women $(\mathrm{n}=352)$} & \multicolumn{2}{l|}{ Gender } & \multicolumn{2}{l|}{ Men $(\mathrm{n}=216)$} & \multicolumn{2}{l|}{ Women $(\mathrm{n}=352)$} \\
\hline Variable & $\mathrm{M}$ & $\mathrm{Mdn}$ & $\mathrm{s}$ & $\mathrm{M}$ & $\mathrm{Mdn}$ & $\mathrm{s}$ & Variable & M & Mdn & S & M & Mdn & $\mathrm{s}$ \\
\hline X11 & 3.81 & 4 & 1.142 & 3.85 & 4 & 1.158 & X61 & 3.10 & 3 & 1.036 & 3.19 & 4 & 1.089 \\
\hline X12* & $\mathbf{3 . 0 9}$ & $\mathbf{3}$ & $\mathbf{0 . 9 7 2}$ & $\mathbf{3 . 2 9}$ & $\mathbf{4}$ & $\mathbf{0 . 9 5 8}$ & X62 & 3.49 & 4 & 1.061 & 3.51 & 4 & 0.984 \\
\hline X13 & 2.54 & 2 & 0.997 & 2.62 & 3 & 0.898 & X63 & 3.46 & 4 & 1.025 & 3.53 & 4 & 1.001 \\
\hline X14 & 2.57 & 2 & 0.838 & 2.51 & 2 & 0.861 & X64 & 3.29 & 4 & 0.956 & 3.30 & 4 & 0.991 \\
\hline X21 & 2.46 & 2 & 1.024 & 2.50 & 2 & 0.978 & X71 & 2.95 & 2 & 1.170 & 2.80 & 2 & 1.139 \\
\hline X22 & 2.35 & 2 & 0.913 & 2.39 & 2 & 0.957 & X72 & 3.72 & 4 & 0.903 & 3.85 & 4 & 0.843 \\
\hline X23 & 2.66 & 2 & 0.951 & 2.60 & 2 & 0.964 & X73 & 4.02 & 4 & 0.795 & 4.12 & 4 & 0.795 \\
\hline
\end{tabular}


The International Journal

ENTREPRENEURSHIP AND SUSTAINABILITY ISSUES

ISSN 2345-0282 (online) http://jssidoi.org/jesi/

2018 Volume 8 Number 2 (December)

http://doi.org/10.9770/jesi.2018.8.2(33)

\begin{tabular}{|c|c|c|c|c|c|c|c|c|c|c|c|c|c|}
\hline X24 & 2.47 & 2 & 0.945 & 2.60 & 2 & $\mid 0.901$ & X74 & 2.77 & 2 & 1.145 & 2.76 & 2 & 1.074 \\
\hline X31 & 2.52 & 2 & 0.988 & 2.49 & 2 & 0.961 & X81* & 3.42 & 4 & 1.022 & 3.20 & 3 & 0.988 \\
\hline X32 & 2.70 & 2 & 0.949 & 2.60 & 2 & \begin{tabular}{|l|}
0.925 \\
\end{tabular} & X82* & 3.18 & 3 & 1.001 & 2.97 & 3 & 1.011 \\
\hline $\mathrm{X} 33$ & 3.20 & 3 & 0.956 & 3.05 & 3 & 0.952 & $\mathrm{X} 83$ & 3.80 & 4 & 0.804 & 3.82 & 4 & 0.762 \\
\hline X34* & 2.93 & 3 & 0.966 & 2.75 & 3 & 0.915 & $\mathrm{X} 84$ & 4.07 & 4 & 0.777 & 4.00 & 4 & 0.702 \\
\hline $\mathrm{X} 41$ & 2.46 & 2 & 0.983 & 2.45 & 2 & 0.945 & X91* & 2.68 & 2 & 1.045 & 2.86 & 3 & 0.970 \\
\hline $\mathrm{X} 42$ & 3.07 & 3 & 0.986 & 3.15 & 3 & 0.955 & X92**** & 3.25 & 4 & 1.053 & 3.56 & 4 & 0.904 \\
\hline $\mathrm{X} 43$ & 2.88 & 3 & 1.066 & 2.91 & 3 & 0.923 & X93 & 3.17 & 3 & 1.104 & 3.18 & 3 & 1.111 \\
\hline X44 & 2.48 & 2 & 1.011 & 2.54 & 3 & \begin{tabular}{|l|}
0.957 \\
\end{tabular} & X94** & 2.66 & 3 & 0.931 & 2.46 & 2 & 0.833 \\
\hline X51 & 2.57 & 2 & 0.971 & 2.68 & 2 & 0.956 & $\mathbf{Y 1} * * *$ & 3.68 & 4 & 1.067 & 3.39 & 4 & 1.043 \\
\hline X52 & 3.38 & 4 & 0.870 & 3.34 & 4 & \begin{tabular}{|l|l|}
0.860 \\
\end{tabular} & $\mathbf{Y 2 * * *}$ & 3.25 & 3 & 1.154 & 2.86 & 3 & 1.037 \\
\hline $\mathrm{X} 53$ & 3.26 & 3 & 0.863 & 3.31 & 4 & 0.837 & $\mathbf{Y} 3^{* * * *}$ & 3.01 & 3 & 1.110 & 2.70 & 3 & 0.975 \\
\hline X54** & 3.30 & 3 & 0.882 & 3.10 & 3 & \begin{tabular}{|l|}
0.870 \\
\end{tabular} & Y4**** & 2.44 & 2 & 1.215 & 2.06 & 2 & 1.020 \\
\hline
\end{tabular}

Notes: M - arithmetic mean; Mdn - median; $\mathrm{s}$ - sample standard deviation, $* \mathrm{p}<0.05 \wedge \mathrm{p} \geq 0.01 ;{ }^{* *} \mathrm{p}<0.01 \wedge \mathrm{p} \geq 0.001 ; * * * \mathrm{p}<0.001$.

Source: own processing

The four dependent variables stated as Y1 to Y4 seem to have quite high sample standard deviations for the both genders. For the male population, it is little bit higher than for the female population. From the whole data set, the highest values of sample standard deviation are reached just right by the dependent variables. The number 4 as median is recorded only in a few cases up to the X61 indicator, but then it is the most frequent answer of the respondents.

From the table we can see that measure of agreement with entrepreneurship environment statements is significantly larger in group of men in comparison with women in case of following indicators:

X34 (Present level of basic macroeconomic factors (GDP, employment, inflation) supports entrepreneurship and creates interesting entrepreneurship opportunities),

X54 (The interest rates of commercial banks support entrepreneurship activities),

X81 (The advantages of entrepreneurship outnumber the disadvantages),

X82 (An entrepreneur is wealthier and having a higher social status),

X94 (The disadvantage of doing entrepreneurship is not having good reputation within society).

On the other, side women were more likely to agree in case of:

X12 (Society in general appreciates entrepreneurs),

X91 (The disadvantages of entrepreneurship outnumber the advantages),

X92 (The disadvantage of doing entrepreneurship is not having a regular income).

These indicators seem to be statistically significantly larger for male population than for female population. The disparities in evaluation of these indicators are at a level of few tenths generally. For the X12 indicator it is at a level of 0.2 for the female population, for X34 indicator it is 0.18 for the male population, the X54 indicator -0.2 for the male population, the X81 indicator -0.22 for the male population, the X82 indicator -0.21 for the male population, the X91 indicator -0.18 for the female population, the X92 indicator -0.31 for the female population, and finally the X94 indicator -0.2 for the male population.

The significant differences of entrepreneurship environmental statements between men and women are depicted in error bar plot (95\% confidence interval of arithmetic mean, graph 1). We must remark that indicator X91 (The disadvantages of entrepreneurship outnumber the advantages) was excluded from further analyses because of its 
redundant information in comparison with X81 (The advantages of entrepreneurship outnumber the disadvantages). Both indicators have got the same meaning: X81 is positive about entrepreneurship advantages while X91 is rather negative.

It is interesting that there are no differences in indicators by gender in following entrepreneurship environmental groups: E2 (Entrepreneurial support from state), E4 (Quality of entrepreneurship environment), E6 (Quality of university education) and E7 (Personality traits).

On the opposite all four output indicators of entrepreneurial propensity are highly dependent on gender. From input entrepreneurship environmental, indicators seem to be the most often significant (three from four) are indicators of group E8 (Entrepreneurship disadvantages).

The following Figure 1 demonstrates error ranges of the individual indicators.

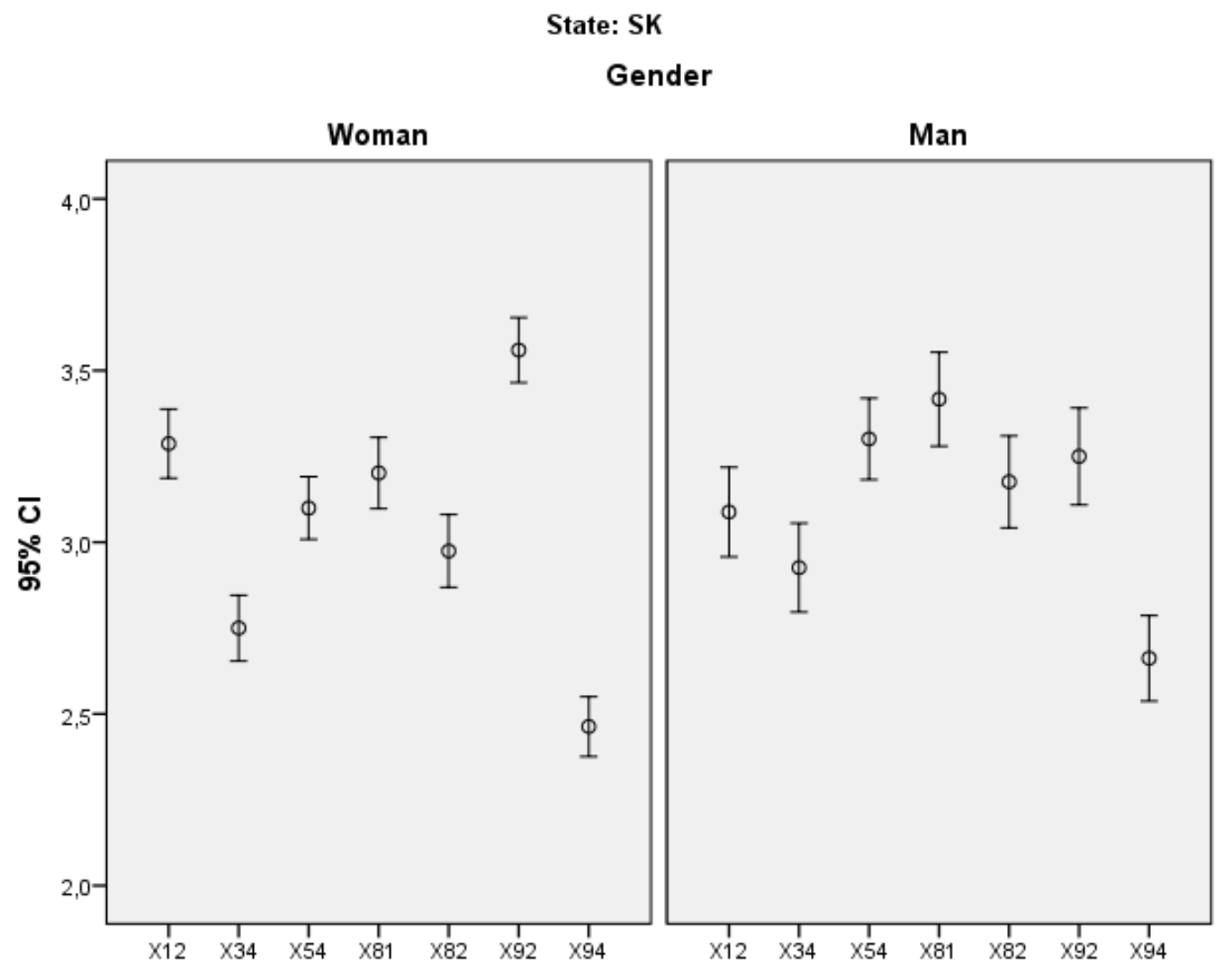

Fig.1. Error bar plot of significant differences in agreement with entrepreneurship environmental statements between students - men and students - women

Source: own processing

Differences in all four output indicators of entrepreneurial propensity were significant:

Y1 (I am very interested in entrepreneurship),

Y2 (I am convinced that I will start an entrepreneurship after I graduate from university),

Y3 (In case nothing unexpected happens, I will start an entrepreneurship within three years latest),

Y4 (At present, I have entrepreneurship activities). 
And in all of them were location parameters larger in group of men in comparison with women $(p<0,001$; see also figure 2). So men are more self-confident from the viewpoint of actual and possible entrepreneurship. The gender differences are at an approximate level of a few tenths. In a case of the Y1 dependent variable, the disparity is calculated at a level of 0.29 , the Y2 variable difference is at level of 0.39 , the Y3 variable -0.31 and finally, the Y4 variable - 0.38. All the dependent variables are differentiated towards the male population.

Figure 2 visualises rangeof error rate of the significant differences according to entrepreneurship propensity statements between men and women.

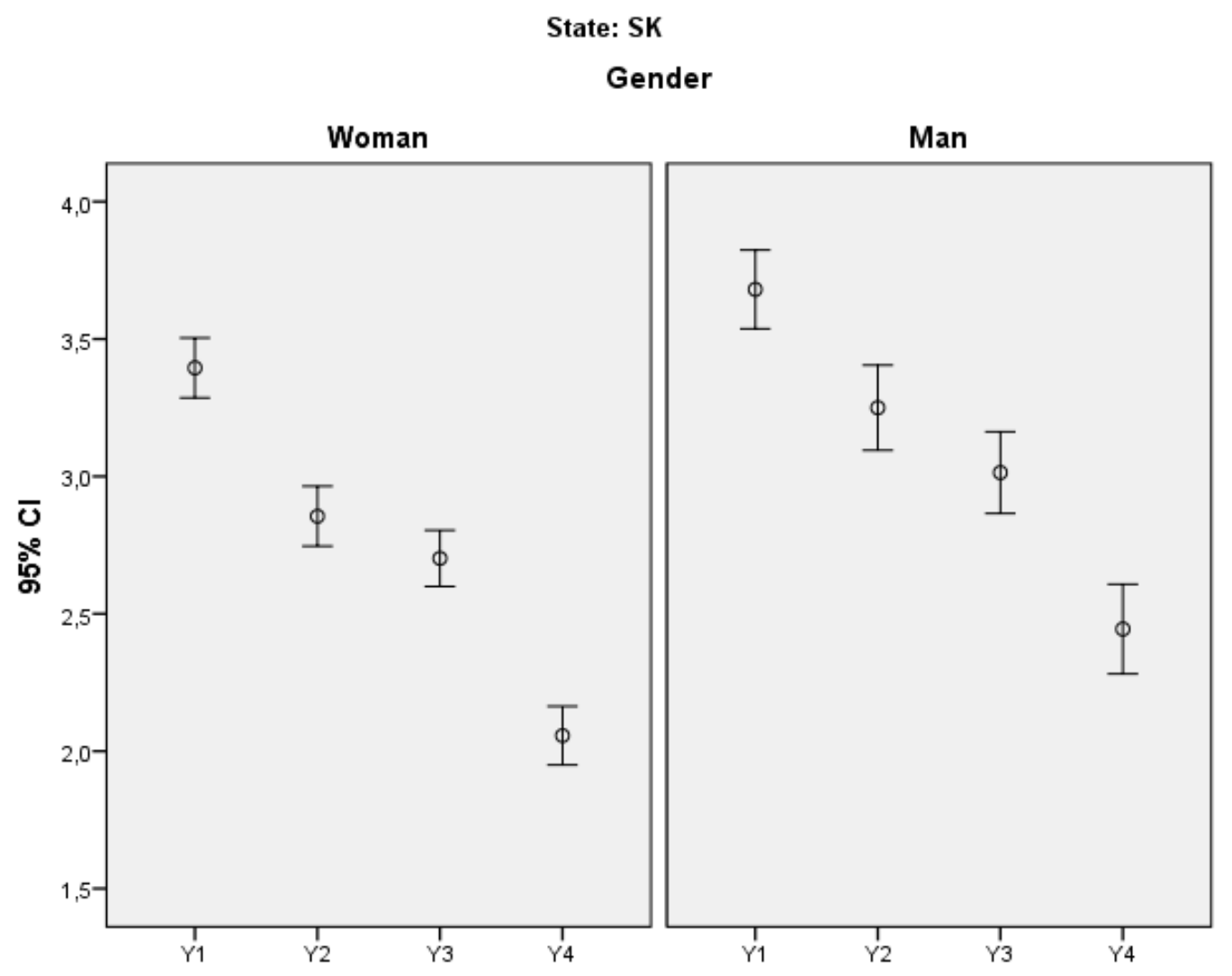

Fig.2. Error bar plot of significant differences in agreement with entrepreneurship propensity statements between men and women

Source: own processing

Next objective was to find out multivariate dependence of gender on a few entrepreneurship indicators. For achievement of the objective we used stepwise discriminant analysis. From original count of 12 univariate significant differences in all entrepreneurship predictors by gender stepwise discriminant analysis has found five. In table 2, there are results of stepwise discriminant analysis. In the first step algorithm included indicator Y2 (I am convinced that I will start an entrepreneurship after I graduate from university). At second was added indicator X92 (The disadvantage of doing entrepreneurship is not having a regular income). The third significant indicator was X12 (Society in general appreciates entrepreneurs). Last two included indicators are X54 (The interest rates of commercial banks support entrepreneurship activities) and Y4 (At present, I have entrepreneurship activities). All involved indicators are highly significant $(\mathrm{p}<0,001)$. 
Table 2 reveals statistical significance of the variables involved in the analysis.

Table 2. Significant entrepreneurship predictors of gender of Slovak university students found by stepwise discriminant analysis

\begin{tabular}{|c|c|c|c|c|c|c|c|c|c|}
\hline \multirow[b]{3}{*}{ Step } & \multirow[b]{3}{*}{ Entered } & \multicolumn{8}{|c|}{ Wilks' Lambda } \\
\hline & & \multirow[b]{2}{*}{ Statistic } & \multirow[b]{2}{*}{ df1 } & \multirow[b]{2}{*}{ df 2} & \multirow[b]{2}{*}{ df3 } & \multicolumn{4}{|l|}{ Exact $\mathrm{F}$} \\
\hline & & & & & & Statistic & df1 & df 2 & Sig. \\
\hline 1 & Y2 & 0.970 & 1 & 1 & 566 & 17.790 & 1 & 566 & 0.000 \\
\hline 2 & X92 & 0.948 & 2 & 1 & 566 & 15.472 & 2 & 565 & 0.000 \\
\hline 3 & $\mathrm{X} 12$ & 0.931 & 3 & 1 & 566 & 13.919 & 3 & 564 & 0.000 \\
\hline 4 & X54 & 0.921 & 4 & 1 & 566 & 12.086 & 4 & 563 & 0.000 \\
\hline 5 & Y4 & 0.912 & 5 & 1 & 566 & 10.880 & 5 & 562 & 0.000 \\
\hline
\end{tabular}

Source: own processing

The exact F-test reveals that all the variables mentioned in Table 2 come from the same probability distribution. This is the fact important to carry out the whole analysis.

\section{Conclusions}

Economic uncertainty of the labour market and the threat of unemployment require a constant increase in education and skills. One of the Europe 2020 initiatives is to improve entrepreneurial skills and innovation. The importance of the education system in supporting business attitudes and skills has increased in the recent decade. The education system must flexibly respond to changing national and global business environments as well as the economic and social conditions. This requires a consistent preparation of the workforce entering the labour market, which increases the demands for the learning processes. For their quality setting, it is important to know the students' preferences for entrepreneurship, their motives, attitudes and opinions. This was also the goal for our research. On basis of available data gathered by online survey among students of Slovak universities we have got some important results. Gender of students is a significant determinant of attitude toward of both entrepreneurship environment and entrepreneurship propensity. The gender disparities in a field of the explored indicators are quite visible. The male population agree with the statements, which has more general aim - for instance, macroeconomic situation is willing to support entrepreneurship in form of creation of new potential entrepreneurship opportunities along with the interest rates that provides a good background for such support. Also, the male population thinks that all the advantages overweight all the disadvantages and entrepreneurship. The sole personal indicator points to a state of entrepreneur - to its bigger wealth and higher social status. This is confirmed also by the indicators X71 and X74 for the both genders with the values of 2.95 and 2.77 for the male population and 2.80 and 2.76 for the female population respectively. On the other hand, the female population is in agreement with the fact society appreciates entrepreneurs and with the disadvantages - concerning not regular income of entrepreneur and also a fact that all the disadvantages outnumber all the advantages of entrepreneurship. This is curious because for the male population it is absolutely oppositely. To summarise the whole outcome of the analysis, there should be noted that the investigated findings are quite different. This could be an input for the further analysis and a platform for additional research. 
The International Journal

ENTREPRENEURSHIP AND SUSTAINABILITY ISSUES

ISSN 2345-0282 (online) http://jssidoi.org/jesi/

2018 Volume 8 Number 2 (December)

http://doi.org/10.9770/jesi.2018.8.2(33)

\section{References}

Androniceanu, A. (2015). Good democratic governance based on a new model. Administratie si Management Public (24), 44-55.

Askun, B., Yıldırım, N. (2011). Insights On Entrepreneurship Education In Public Universities In Turkey: Creating Entrepreneurs Or Not? Procedia Social and Behavioral Sciences 24, 663-676. https://doi.org/10.1016/j.sbspro.2011.09.050

Bedzsula, B. et al. (2016). Quality Improvement Based on a Process Management Approach, with a Focus on University Student Satisfaction. Acta Polytechnica Hungarica 13(6), 87-107.

Belas, J., Gavurova, B., Schonfeld, J., Zvarikova, K., Kacerauskas, T. (2017). Social and Economic Factors Affecting the Entrepreneurial Intention of University Students. Transformations in Business \& Economics, 16(3), 220-239.

Bellotti, F., Berta, R., De Gloria, A., Lavagnino, E., Dagnino, F., Ott, M., Romero, M., Usart, M., Mayer, I. S. (2012). Designing a Course for Stimulating Entrepreneurship in Higher Education through Serious Games. Procedia Computer Science 15, 174-186. https://doi.org/10.1016/j.procs.2012.10.069

Cavaller, V. (2011). Portfolios for entrepreneurship and self-evaluation of higher education institutions. Procedia Social and Behavioral Sciences 12, 19-23. International Conference on Education and Education Psychology 2010. https://doi.org/10.1016/j.sbspro.2011.02.005

Dobeš, K., Kot, S., Kramoliš, J., Sopková, G. (2017). The Perception of Governmental Support in The Context of Competitiveness of SMEs in the Czech Republic. Journal of Competitiveness, 9(3), 34-50. https://doi.org/10.7441/joc.2017.03.03

Dragolea, L., Grondys, K., Sroka, M. (2017). Career Management: Short Analysis Regarding Interest on Employment Fields Among Youths. Polish Journal of Management Studies 16 (2), 62-73. https://doi.org/10.17512/pjms.2017.16.2.06

Dul’ová Spišáková, E., Mura, L., Gontkovičová, B., Hajduová, Z. (2017). R\&D in the context of Europe 2020 in selected countries. Economic Computation and Economic Cybernetics Studies and Research 51(4), 243-261.

Estaswara, H. (2016). Integrated Marketing Communications (IMC) in Higher Education in Indonesia. Polish Journal of Management Studies, 14 (1), 74-83. https://doi.org/10.17512/pjms.2016.14.1.07

Ključnikov, A., Belás, J., Kozubíková, L., Paseková, P. (2016). The Entreprenurial Perception of SME Business Environment Quality in the Czech Republic. Journal of Competitiveness, 8(1), 66-78. https://doi.org/10.7441/joc.2016.01.05

Kozubíková, L., Homolka, L., Kristalas, D. (2017). The Effect of Business Environment and Entrepreneurs' Gender on Perception of Financial Risk in The Smes Sector. Journal of Competitiveness, 9(1), 36-50. https://doi.org/10.7441/joc.2017.01.03

Machová, R., Mura, L., Havierniková, K., Tóth, Z. (2017). The entrepreneur's network as a cooperation form of entrepreneurship: Case of Slovakia. Journal of Applied Economic Sciences 12(1), 160-169.

Misoska, A. T., Dimitrova, M., Mrsik, J. (2016). Drivers of entrepreneurial intentions among business students in Macedonia. Economic Research-Ekonomska Istraživanja 29(1), 1062-1074, https://doi.org/10.1080/1331677X.2016.1211956

Pihie, Z. A. L., Bagheri, A. (2011). Teachers' and Students' Entrepreneurial Self-efficacy: Implication for Effective Teaching Practices. Procedia - Social and Behavioral Sciences 29, 1071-1080. International Conference on Education and Educational Psychology (ICEEPSY 2011). https://doi.org/10.1016/j.sbspro.2011.11.340

Riel, A., Tichkiewitch, S., Paris, H. (2015). Preparing Researchers for Entrepreneurship based on Systematic Innovation Training. Procedia Engineering 131, 933-940. World Conference: TRIZ FUTURE, TF 2011-2014. https://doi.org/10.1016/j.proeng.2015.12.405

Staniewski, M., Awruk, K. (2015). Motivating factors and barriers in the commencement of one's own business for potential entrepreneurs. Economic Research-Ekonomska Istraživanja 28(1), 583-592. https://doi.org/10.1080/1331677X.2015.1083876 
The International Journal

ENTREPRENEURSHIP AND SUSTAINABILITY ISSUES

ISSN 2345-0282 (online) http://jssidoi.org/jesi/

2018 Volume 8 Number 2 (December)

http://doi.org/10.9770/jesi.2018.8.2(33)

Stankevičiené, J., Kraujaliené, L., Vaiciukevičiüté, A. (2017). Assessment of technology transfer office performance for value creation in higher education institutions. Journal of Business Economics and Management 18(6), 1063-1081. https://doi.org/10.3846/16111699.2017.1405841

Torres, F. C., Mendez, J. C. E., Barreto, K. S., Chavarria, A. P., Machuca, K. J., Guerrero, J. A. O. (2017). Exploring entrepreneurial intentions in Latin American university students. International Journal of Psyhological Research 10(2), 46-59. https://doi.org/10.21500/20112084.2794

Upadhyay, S. (2017). Can Spiritual Intelligence Influence Research Performance in Higher Education? Framework for Human Resource Development in Higher Educationa. Administratie si Management Public (28), 153-173.

\section{Short biographical note about the contributors}

Jaroslav Belas, Ph.D is a Full Professor. He is a renowned expert in commercial banking and risk management of SMEs. He worked in the Slovakian banking sector from 1993 to 2001. With regards to the academic field, he has worked at the University of Economics in Bratislava and the Pan European University in Bratislava. He is currently at Tomas Bata University in Zlin, Faculty of Management and Economics. He is an author of 9 monographs; the results of the research activities have been included in 70 various scientific papers that have been published in prestigious journals. He is a member of the Scientific Council of Pan European University in Bratislava and the Scientific Council of Georg Žilina publisher in Slovakia.

ORCID ID:

Beata Gavurova, PhD. is Associate Professor at Department of Banking and Investment, Faculty of Economics, Technical University of Košice. She is an expert in finance, financial analysis and financial risk management. In her research work she focuses on issues of measurement and performance management in various sectors, process management and process optimisation, strategic and performance benchmarking. Her dominant research area is the development and testing in management and performance measurement, evaluation of methodologies and preparing the application platform for innovative management and performance measurement with the support of ICT. ORCID ID:

Dr. Martin Cepel is an expert in business environment and risk management of SMEs. He is currently working at Paneuropean University in Bratislava, Faculty of Economics and Business. The results of the research activities have been outputted in various scientific works that have been published in prestigious journals which are indexed on Web of Science and Scopus.

ORCID ID:

Anna Kotaskova is a PhD. student at Faculty of Economics and Business, Paneuropean University in Slovakia. Bachelor Degree in Economics and Business Management and Master Degree in International Entrepreneurship at Paneuropean University. Her research focuses on entrepreneurship with emphasis on SMEs' segment, the quality of business environment for SMEs, SMEs financing and performance, as well as on macroeconomics in general. She has published some articles in journals which are indexed on Web of Science and Scopus.

ORCID ID:

Register for an ORCID ID:

https://orcid.org/register

Copyright (C) 2018 by author(s) and VsI Entrepreneurship and Sustainability Center

This work is licensed under the Creative Commons Attribution International License (CC BY).

http://creativecommons.org/licenses/by/4.0/

(c) (i) Open Access 